\title{
Diffusion of Regulatory Innovations: The Case of Corporate Governance Codes
}

\section{CARSTEN GERNER-BEUERLE*}

Law Department, London School of Economics and Political Science, United Kingdom

\begin{abstract}
Since the 1990s, most European countries have adopted detailed corporate governance codes regulating listed companies. Even though the initial codes were designed against the backdrop of a particular jurisdiction, best practice standards have become remarkably similar across legal traditions. This raises the question whether the codes are sufficiently responsive to local conditions, or standard setters are mainly motivated by the concern not to fall behind internationally accepted benchmark standards. The article quantifies central corporate governance provisions and maps their international diffusion. Controlling for differences in legal families and ownership structure, the article shows that the diffusion of best practice standards leads to a statistically significant increase in the likelihood that a foreign standard setter will adopt a broadly similar provision. The findings indicate that codes are often seen as signalling devices, irrespective of whether or not the adopted standards are well aligned with the domestic economic and legal environment.
\end{abstract}

\footnotetext{
*Email: c.gerner-beuerle @ 1se.ac.uk. I am grateful to John Armour, Dan Awrey, André Betzer, Michael Blackwell, Brian Cheffins, Paul Davies, Daniel Ferreira, Lars Hornuf, David Kershaw, Tom Kirchmaier, Edmund-Philipp Schuster, Mathias Siems, Hanne Søndergaard Birkmose, Moqi Xu, Stefan Zeume, the two anonymous reviewers of the JOIE, and the participants of conferences and seminars at Aix-Marseille Université, Duke University, London School of Economics, National University of Singapore, University of Oxford, Department of Financial \& Management Studies, SOAS, and the University of St. Gallen for valuable comments on previous versions of this article. Financial support of this research by the Law and Financial Markets Project, LSE, is gratefully acknowledged. All mistakes are mine.
} 


\section{Introduction}

In 1992, a British committee composed of businessmen, accountants, and members of independent regulators, the so-called Cadbury Committee, produced a report entitled "The Financial Aspects of Corporate Governance", which was concerned with the perceived lack of accountability of corporate boards in the UK. It contained a Code of Best Practice making various recommendations in order to improve the control and reporting functions of boards. These recommendations included the requirement to provide for "a clearly accepted division of responsibilities at the head of a company", appoint "non-executive directors of sufficient calibre and number" to the board, ensure that the majority of the non-executive directors were "independent of management and free from any business or other relationship which could materially interfere with the exercise of their independent judgement", and establish non-executive board committees to deal with questions of executive compensation and internal control. ${ }^{1}$

The publication of the Cadbury Code was what can be called the birth of the corporate governance movement in Europe. More than two decades later, virtually all European countries, and a considerable number of countries worldwide, have adopted corporate governance codes that apply on a comply-or-explain basis to companies listed on national stock exchanges. The regulatory innovations promulgated in the Cadbury Code have been taken up by other corporate governance codes, and concepts such as "independent non-executive director" or "remuneration committee" are now commonplace. This poses a question that is, arguably, asked too rarely, both by academics and policy makers, and that has not been answered convincingly by either of these groups (or others) involved in the corporate governance debate. The Cadbury Report presented a response to specific problems afflicting the British corporate economy in the late 1980s and early 1990s, accentuated by well-known corporate scandals such as the Guinness share-trading fraud or the collapse of Robert Maxwell's media empire. The Code's best practice standards were developed against the backdrop of a specific legal

\footnotetext{
${ }^{1}$ Cadbury Report (1992), Best Practice Rules 1.2, 1.3, 2.2, 3.3 and 4.3.
} 
system and reflected "existing best practice" in British companies (Cadbury Report 1992, 1.7). The Committee did not intend to replace British corporate governance structures and practices, but build on them and enhance them to strengthen their effectiveness. Thus, it can be said that the drafters of the Cadbury Code expected the code's best practice standards to be effective, given the prevalence of certain economic and legal conditions in Britain at the time.

The question that this article is concerned with, accordingly, is the following: Why should policy makers in other legal systems, operating under a different set of economic and legal constraints, adopt provisions that are, at least at first sight (this point will be addressed more formally below), similar to those developed by the Cadbury Committee? Relevant differences that influence potentially the effectiveness of best practice standards include the binding legal environment, most importantly the choice between a one-tier and two-tier board structure, but also other requirements affecting board composition, such as rules on co-determination or gender quotas, and the ownership structure of public companies. Widely dispersed shareholders may be more reliant on strong independent directors than blockholders who are able to control management effectively. In the latter case, providing for a regulatory environment that is attractive to outside investors may involve implementing safeguards against rent seeking by the majority owners, rather than focusing on the managerial agency problem. If corporate governance rules promulgated by foreign standard setters are emulated simply because they are internationally perceived as "best practice", without being responsive to local economic or legal conditions, they risk being irrelevant at best and harmful to business because of increased compliance costs and legal uncertainty at worst.

It is important to emphasise that this study does not assess the efficiency of corporate governance rules as implemented in different countries. A large number of publications have addressed this point, and the discussion in the literature often centres on determining whether governance structures cause economic outcomes or arise endogenously in response to particular firm characteristics (e.g. Armstrong, Core and Guay 2014; a literature survey is given by Adams, Hermalin and Weisbach 2010). In contrast, this study focuses on what can be called the "political economy side" of corporate governance regulation. I seek to understand how novel regulatory concepts, for example independence 
of directors or delegated decision-making by board committees, spread from one country to another and why standard setters in other countries emulate regulatory innovations initially promulgated under distinct legal and economic conditions.

In order to answer these questions not only in an intuitive manner, but by providing empirical evidence, it is necessary (1) to identify a number of regulatory concepts typically contained in corporate governance codes (as opposed to national legislation) that can, accordingly, be traced by mapping the adoption of codes internationally; (2) define what is meant with "similar rules", which involves determining a formulation of the regulatory concept at issue that can be used as a standard for comparison with the formulations actually found in corporate governance codes, and further developing a metric that allows the quantification of the distance between the two formulations; and (3) analyse the association between the differences thus found and predictors capturing potentially influential features of the economic and legal environment.

Thus, the article relates to different strands of the literature: the corporate governance literature; research dealing with the methodological problems of quantifying legal rules; and the diffusion of innovations. Research on the spread of corporate governance codes is relatively limited. Zanetti and Cuomo (2008) find that common law countries are more likely to issue stringent recommendations than civil law countries. Aguilera and Cuervo-Cazurra $(2004,2009)$ argue that the diffusion of codes occurs both in order to compensate for deficiencies in a country's investor protection system and to increase legitimacy in the eyes of foreign investors. However, in contrast to this article, they do not analyse the content of codes and hence do not measure how individual, clearly defined best practice standards have spread across borders, but simply ask whether a country has adopted a code. In addition, none of the above studies examines the effect that the process of diffusion itself has on the probability of code adoption.

Measuring the "distance" between two formulations of a best practice standard requires the quantification of these standards. Whether legal rules and regulations are susceptible to quantitative analysis, and if yes, how rules should be quantified, is probably the most controversial aspects of the 
strand of research that has become known as "law and finance". Since the pioneering work of La Porta et al. $(1997,1998,2000)$, the methodology of quantifying legal rules has been highly controversial, and some scholar have questioned the usefulness of quantitative legal research altogether (Siems, 2005b). Prior research has been criticized for not taking account of the existence of functional substitutes, interactions between norms, and difficulties in the comparison of norms that were structured and conceptualised against the backdrop of different jurisdictions and legal traditions (for some contributions from the voluminous literature, see Armour et al., 2009a; Siems, 2005a, 2007; Spamann, 2006, 2009a). Furthermore, it has been pointed out that binary coding systems, such as the one employed by La Porta et al. (1998), fail to appreciate nuances in the operation of legal rules (Armour et al., 2009b; Siems, 2005a; Spamann, 2006). Surprisingly, while the question of how to code norms is of central importance to empirical legal research, Epstein and Martin (2010) observe that almost no attempt has been made to develop a sound methodological foundation for this type of research, with the exception of a few legal studies, notably Siems (2005b) and Spamann (2009b). This article seeks to contribute to the still evolving methodological debate. Section 3 discusses the challenges that the quantification of legal rules or best practice standards involves. It identifies best practice standards that can be coded meaningfully without running the risk of overlooking functional substitutes and develops a quantification method that is responsive to normative nuances and able to resolve ambiguities, while ensuring consistency in coding.

Finally, research on the diffusion of innovations, pioneered by Rogers 2003, is wide-ranging and includes studies examining the diffusion of technical innovations, models of management, social attitudes, and public policies (overviews are given by Graham et al., 2013; Strang and Soule, 1998). However, in spite of the large number of diffusion studies, few deal with issues related to law or regulatory practices, and none with the diffusion of individual best practice standards in corporate governance. Aguilera and Cuervo-Cazurra (2004, 2009) and Zanetti and Cuomo (2008) examine the spread of corporate governance codes as a whole. Twining (2005) offers a theoretical discussion of the diffusion of law, but does not model the diffusion of specific regulatory innovations. Other examples include Canon and Baum (1981), who study the diffusion of tort doctrines in US state courts, and Davis 
and Greve (1997), who analyse the spread of poison pills. The present study contributes to this literature by providing the first formal model of the international diffusion of best practice standards in corporate governance codes, building on empirical diffusion studies that focus on the effect of prior adoptions (e.g. Burns and Wholey, 1993). While an analysis of the precise channels of diffusion is beyond the scope of the article, it lays the groundwork for future research by assessing how widely and how fast corporate governance innovations spread and whether past diffusion is associated with the likelihood of future adoption.

The remainder of the article is organised as follows. Section 2 formulates the hypotheses that will be tested empirically. Section 3 addresses the methodological challenges in quantifying best practice standards and specifies the empirical model. Section 4 presents the results of the Cox regression analysis. Section 5 discusses the findings and concludes.

\section{Theory and hypotheses}

Aguilera and Cuervo-Cazurra (2009) explain that the diffusion of corporate governance codes may be a function of two factors: efficiency accounts and social legitimation. According to the former, corporate governance reform leads to efficiency gains by addressing shortcomings in the existing legal system. The need for social legitimation, on the other hand, is explained with the pressures of globalisation and increased flows of capital. In an economy that depends to a comparatively greater extent on foreign trade and investment inflows, corporate governance codes are more likely to serve primarily as a signal to foreign investors that appropriate governance mechanisms are in place, irrespective of actual efficiency gains from an improved legal system. Aguilera and Cuervo-Cazurra test this hypothesis by examining whether a country's openness to trade (imports and exports as a percentage of GDP) and foreign portfolio investment flows are positively associated with the likelihood that the country will adopt a corporate governance code. However, it is difficult to disentangle efficiency and legitimation considerations in this way. For example, the increased presence of foreign portfolio investors changes the ownership structure of the domestic corporate economy, and as a result the effectiveness of certain legal mechanisms may need to be reassessed. Notably, strategies to protect 
minority shareholders, for example minority representation on the board, gain in importance. It is suggested that the signalling function of corporate governance codes can be tested better by assessing the effect that the emergence of internationally accepted standards of best practice has on the activities of code issuers. As explained, this is possible with the data compiled for this article because best practice standards relating to the structure of corporate boards (identified more precisely in Section 3) are coded, so that the adoption of standards corresponding to specific definitions can be determined precisely and traced across countries and over time. If codes were used as a signal, rather than to increase the effectiveness of the domestic regulatory environment, we would expect code issuers to be responsive to the international diffusion of best practice standards, controlling for differences in a country's legal system and investment flows. Therefore, I propose to use the number of code issuers having adopted a similarly formulated best practice standard at any given point in time as a predictor of future adoption of this best practice standard and hypothesise accordingly:

H1: The likelihood that a code issuer will adopt a particular best practice standard on board structure increases as the number of corporate governance codes in force in other countries that contain such a best practice standard increases.

In contrast to Aguilera and Cuervo-Cazurra (2009), this predictor, arguably, captures the effect of diffusion as such, whereas Aguilera and Cuervo-Cazurra focus on what Strang and Soule (1998) call "external sources" of diffusion. It is, of course, important to investigate the role of such external factors as well. As pointed out by Aguilera and Cuervo-Cazurra (2009), a country's integration into the global economy may lead to greater legitimation pressures or, as mentioned above, to economic changes that necessitate a different regulation of the corporate economy. In particular, the rise of institutional investors and the changing ownership structure of firms are well documented (Gilson and Gordon, 2013; Kahan and Rock, 2010). Scholars have related these developments to changes in the regulatory environment. Famously, La Porta et al. (1998) argue that strong investor protection laws are negatively associated with concentrated ownership structure. Ferreira and Matos (2008) show that domestic institutional investors have a preference for strong minority shareholder rights. Thus, it is possible that the presence of domestic and/or foreign institutional investors is associated with a higher likelihood that 
internationally accepted best practice standards are adopted. Such an association can be explained with both efficiency and legitimacy considerations. The best practice standards may be adopted because the drafting committee believes that such standards constitute an appropriate response to the actual regulatory needs of institutional and foreign investors, which presupposes that the focus of the best practice standards is on protecting minority shareholder interests, for example by decoupling management and control functions on the board of directors. As will be discussed in Section 3.1, this is indeed how a comparatively higher score in the regulatory variables computed here can be interpreted. Alternatively, the corporate governance committee may seek to meet the expectations or preferences of investors, which would be in line with the legitimation account, without involving any statement about the efficiency of the regulatory change. I hence contend that:

H2a: Economies with a comparatively large presence of foreign investors are associated with the adoption of best practice standards that are perceived to protect their interests.

H2b: Economies with a comparatively large presence of domestic institutional investors are associated with the adoption of best practice standards that are perceived to protect their interests.

Conversely, if ownership structure is dominated by corporate insiders (blockholders), we may expect drafting committees to be responsive to the regulatory needs or expectations of the insiders, and accordingly adopt best practice standards that do not focus on strengthening control and constraining managerial discretion. ${ }^{2}$ We can therefore also formulate:

H2c: Economies with a comparatively large presence of blockholders are negatively associated with the adoption of best practice standards that are perceived to protect the interests of foreign and/or domestic institutional investors.

Finally, it is a long-standing claim of the law and finance literature that common law countries have a predisposition to stronger (minority) investor protection than German or French legal origin

\footnotetext{
${ }^{2}$ Again, as will be discussed in Section 3.1, this would correspond to a comparatively lower score in the regulatory variables.
} 
countries (La Porta et al., 1997, 1998, 2000; Djankov et al., 2008). The diffusion literature builds on this claim to test whether corporate governance codes are adopted to compensate for deficiencies in a country's binding company law (Aguilera and Cuervo-Cazurra, 2009; Zanetti and Cuomo, 2008). It is questionable whether La Porta et al.'s claim should be embraced in this generality for present purposes. The methodological problems surrounding this strand of research have been mentioned in Section 1 above. Armour et al. (2009b) and Siems (2005a) have also criticised La Porta et al.'s classification of legal systems into four broad legal families (common law, German, French and Scandinavian legal origins) for overstating the differences between legal systems and neglecting the hybrid nature of many jurisdictions. It is indeed questionable whether characteristics such as general regulatory ideologies can be attributed to legal systems as a whole and whether these characteristics, if they exist, are uniquely and exogenously determined by a jurisdiction's legal origins, as La Porta et al. claim. However, in individual legal areas, including corporate governance, distinct regulatory strategies can be identified that correlate within, but not between legal families (Gerner-Beuerle and Schuster, 2014). In the same manner, the likelihood that a particular best practice standard is adopted may vary between legal families. It is important to emphasise that such variation, if it indeed existed, would not be an indication of a high or low level of investor protection. As Cools (2005) has convincingly argued, the absence of a particular regulatory strategy may simply be the result of the use of substitute mechanisms in a different part of the legal system. With this caveat in mind, testing for legal origins can inform us about the regulatory technique preferred by a country: soft law or binding legislative measures.

Theory and prior research are ambiguous in the direction of the association between legal origins and the adoption of stringent best practice standards. If the findings by Zanetti and Cuomo (2008) that civil law countries tend to adopt more ambiguous and lenient recommendations apply to the best practice standards analysed here, or if Cools (2005) is correct in her claim that the main channel of investor protection in civil law countries can be found in the allocation of decision rights in company law statutes, we would expect that:

H3a: Civil law countries are negatively associated with the adoption of best practice standards that are perceived to protect the interests of investors, compared with common law countries. 
An alternative account is suggested by Aguilera \& Cuervo-Cazurra (2004), who see corporate governance codes as a mechanism to compensate for otherwise inadequate investor protection rules in civil law countries. If this account holds in the present context, we would expect that:

H3b: Civil law countries are positively associated with the adoption of best practice standards that are perceived to protect the interests of investors, compared with common law countries.

\section{Methodology, data and model specification}

The sample consists of all corporate governance codes adopted in 23 European countries since the publication of the Cadbury Report in 1992 (106 codes in total). These countries were chosen because they have promulgated two or more codes available in English, cover $98 \%$ of the market capitalization of the EEA including Switzerland, ${ }^{3}$ and represent diverse legal traditions. Central provisions of the codes were quantified to calculate a set of "regulatory variables" (Table 1.A, further discussed in Section 3.1 below). In quantifying the provisions, two main methodological challenges had to be addressed, which may be termed the "identification problem" and the "reductionism problem". The former refers to the difficulty in identifying regulatory concepts that can be compared meaningfully, given that legal systems use different regulatory techniques to address the same social conflict and that norms interact in various ways with the legal system in which they are embedded. Second, norms are necessarily to a greater or lesser extent nuanced and open-ended in order to be adaptable to a variety of factual circumstances. The process of quantification, both of best practice standards and binding statutory law, therefore faces the challenge of using interpretation to condense complex normative information into numerical data in a consistent manner and without succumbing to reductionism. I will deal with the two problems in turn.

\footnotetext{
${ }^{3}$ Source: World Bank World Development Indicators.
} 


\subsection{Identification}

Certain issues addressed in corporate governance codes in some jurisdictions may be regulated in binding laws in others. Comparing the regulatory responses to such issues would not render particularly meaningful results since no conclusions could be drawn from the fact that a country did not emulate a best practice standard. It is therefore important to focus on mechanisms that will typically be insulated from the codified corporate law of a country and dealt with predominantly by soft law. In addition, the relevant issues should lend themselves to prescriptive, detailed regulation, as opposed to regulation by means of general guidelines or broad standards, in order to be amenable to coding.

Arguably, both conditions are satisfied by rules that structure the board of directors of listed companies. While basic tenets of board structure regulation, notably the distinction between one-tier and two-tier boards, are generally laid down in binding legislation, the detailed aspects of board structure, such as the number of independent directors or the requirement to establish board committees, are commonly not found in the codified law. These requirements depend on changing characteristics of the company and the market for non-executive directors. To give just a few examples, a small or medium-sized company may find it unnecessarily cumbersome and inefficient to establish separate nomination, remuneration and audit committees. In smaller economies, the market for non-executive directors may not be sufficiently deep to allow companies to find qualified individuals meeting a long list of independence requirements. In some companies, it may be particularly important to retain firmspecific expertise and hence allow retiring executives to continue to serve in a non-executive capacity on the board of directors or supervisory board. The comply-or-explain principle of corporate governance codes is more appropriate to regulate these issues than binding law. Indeed, board structure regulation is a centrepiece of all codes analysed in the sample, and often the relevant recommendations contain detailed prescriptions of how boards should be structured. Other issues addressed by corporate governance codes are either less well insulated from the binding company law or formulated in openended terms less amendable to quantification. For example, executive remuneration is increasingly regulated in binding acts, which impose extensive disclosure obligations and more recently also 
shareholder approval requirements, and provisions dealing with shareholder engagement or internal control commonly only establish general guidelines.

It is widely accepted in corporate governance theory (and also by some policy makers) that effective boards should be structured so as to contain a strong non-executive and independent element on the board, avoid a concentration of power at the helm of the company by requiring that the roles of chairman and CEO be separated, and delegate issues that involve particularly pronounced conflicts of interest to independent committees, namely succession planning, responsibility for the review of internal control procedures and the appointment of the external auditor, and remuneration decisions (see, e.g., Mallin, 2015, and Commission Recommendation 2005/162/EC). These considerations of what constitutes good governance have been translated into six elements of board structure regulation: (1) the requirement that at least half of the board shall consist of non-executive directors; (2) a majority of the non-executive directors must be independent; (3) independence is defined prescriptively in the form of an enumeration of factors that must be satisfied, most importantly not having been an executive director or employee of the company in a senior management position for a specified number of years, receiving additional remuneration from the company, representing a major shareholder, or having a significant business relationship or family ties with the company; (4) the roles of CEO and chairman shall not be exercised by the same individual; (5) the CEO shall not become chairman upon retirement as chief executive (cooling-off period); and (6) companies shall establish nomination, audit and remuneration committees composed of a majority of independent non-executive directors (Table 1.A).

These best practice standards form the six variables that measure changes in regulation and determine the value of a second set of variables, called "diffusion variables", which count how many standard setters have adopted a similar formulation of each of the six standards (Table 1.B). The variables are coded by assigning a value between 0 and 1 , as set out in Table 1.A, with higher values representing a comparatively more stringent formulation (from the perspective of the executive directors or corporate insiders). A code provision is "similar" to the definition of the best practice standard used for purposes of comparison (the most stringent alternative of the definitions given in Table 1.A), if the value of the respective variable is equal to or greater than 0.75 . The dichotomous 
indictor variable "adoption of benchmark rule" takes the value 1 if a standard setter adopts a provision similar to the definition, and the dichotomous indictor "regulatory innovation" takes the value 1 if a standard setter changes the code so that the provision is more similar to the comparator definition than before. These dichotomous indicators are used as dependent variables in the empirical models in Section 4.

\section{<Tables 1 and 2 about here>}

While the regulatory variables chosen here operate generally independently of the corporate law in place in the respective jurisdiction, certain interdependencies between soft law and the binding legislative framework are unavoidable. Most importantly, it is clear that the six elements of board structure regulation are not equally applicable to one-tier and two-tier boards. In jurisdictions with a two-tier board structure, executive and non-executive directors are by definition separated and the board ultimately responsible for monitoring, the supervisory board, consists entirely of non-executive directors, who may or may not be independent. Similarly, the positions of chairman of the supervisory board and chairman of the executive board (CEO in Anglo-American parlance) cannot be exercised by the same individual. Thus, elements (1) and (4) are omitted from the analysis if the legal system employs the two-tier board model. The coding protocol contains further explanations, including references to statutory sources where appropriate. ${ }^{4}$

Panel A of Table 2 reports summary statistics. In the first row, 'board structure' is based on the mean of the scores for the six (or four, as applicable) elements of board structure received by the codes in the sample. The other rows report summary statistics for the six individual elements of board structure as well as the ownership variables, Panel B correlation coefficients, and Panel C mean values of the regulatory variables broken down by country.

\footnotetext{
${ }^{4}$ Appendix B.
} 


\subsection{Reductionism}

The second methodological challenge, here called the "reductionism problem", needs to be addressed by all legal research using quantitative methods. Norms are often not phrased in a binary way, but may provide for a catalogue of exceptions or allow market actors to modify or disapply the norm contractually. In addition, a norm may be susceptible to more than one interpretation, and a universally accepted interpretation ensuring legal certainty may not exist. A binary or otherwise not sufficiently nuanced coding system could not capture these aspects and would, therefore, be prone to measurement error and lead to a loss of information. On the other hand, a more gradual quantification necessarily requires judgments to be made that will, to some extent, be conditional on the interpretation found most convincing. Scholars generally do not go so far as to conclude that quantitative techniques are inappropriate in legal scholarship because of these reasons, but they caution against oversimplification and the blind faith in the comparability of any aspect of a legal system (Epstein and Martin, 2010; Michaels, 2009; Siems, 2005b). The key, it seems, is to be aware of the tradeoff between accuracy and objectivity inevitably involved in the quantification of social phenomena that are open to interpretation and rational disagreement about their meaning (Gompers, Ishii and Metrick, 2003).

In order to make allowance for this tradeoff, I propose a two-step approach to coding. The first step consists in a mechanical application of a simple metric that is usually composed of not more than three levels: ${ }^{5}$ a lower bound reflecting the absence of any meaningful regulation of the relevant issue (in which case the variable equals zero), an upper bound reflecting the most stringent regulation practically relevant (the variable equals one), and one intermediate stage reflecting best practice standards that impose meaningful constraints but fall short of the most stringent formulations available (the variable equals 0.5 ). In this first step, any ambivalence in the formulation of the best practice

\footnotetext{
${ }^{5}$ The only exception is the variable "definition of independence". In this case, the enumeration of criteria indicating independence (see for example Commission Recommendation 2005/162/EC, Annex II) lends itself to a more gradual coding.
} 
standard, exemptions or the possibility to disapply the rule, for example upon a motion by shareholders, are disregarded.

In a second step, the value derived in the first step is adjusted if the mechanical quantification does not accurately reflect the true import of the rule. The adjustment is confined to two scenarios that relate to the strictness and precision of the provision. The value is either adjusted if the rule is formulated in an optional way and provides for exemptions or allows non-compliance outside the comply-or-explain principle, i.e. the company is in full compliance with the code, and accordingly is not required to publish an explanation, although the provision is not applied, or the provision is phrased so ambivalently or in such general terms that precise behavioural prescriptions cannot be derived from it. In both cases, the first-step value is adjusted as explained, for each case of adjustment, in the coding protocol. $^{6}$

It may be useful to explain the operation of the two-step analysis with the help of an example. I take element (4), separation of CEO and chairman of the board, and analyse how the UK Corporate Governance Code of 2012 and the Italian Corporate Governance Code of 2011 correspond to the metric developed here. The two code provisions are as follows:

UK Corporate Governance Code 2012, A.2:

\section{Main Principle}

There should be a clear division of responsibilities at the head of the company between the running of the board and the executive responsibility for the running of the company's business. No one individual should have unfettered powers of decision.

\section{Code Provision}

A.2.1. The roles of chairman and chief executive should not be exercised by the same individual. The division of responsibilities between the chairman and chief executive should be clearly established, set out in writing and agreed by the board.

Italian Corporate Governance Code 2011, Article 2:

${ }^{6}$ Appendix B. 


\section{Principles}

2.P.4. It is appropriate to avoid the concentration of corporate offices in one single individual. 2.P.5. Where the Board of Directors has delegated management powers to the chairman, it shall disclose adequate information in the Corporate Governance Report on the reasons for such organisational choice.

\section{Criteria}

2.C.3. The Board shall designate an independent director as lead independent director, in the following circumstances: (i) in the event that the chairman of the Board of Directors is the chief executive officer of the company; (ii) in the event that the office of chairman is held by the person controlling the issuer.

\section{Comment}

The international best practice recommends to avoid the concentration of offices in one single individual without adequate counterbalances; in particular, the separation is often recommended of the roles of chairman and chief executive officer ... The Committee is of the opinion that, also in Italy, the separation of the above-mentioned roles may strengthen the characteristics of impartiality and balance that are required from the chairman of the Board of Directors. The Committee, in acknowledging that the existence of situations of accumulation of the two roles may satisfy, in particular in issuers of smaller size, valuable organizational requirements, recommends that, should this be the case, the figure of the lead independent director be created.

The UK code provides that there should be a clear division of responsibilities at the head of the company and the roles of chairman and chief executive should not be exercised by the same individual. This falls squarely within the upper bound of the definition of element (4). The provision is unambiguous and does not contain any qualifications or exemptions. Therefore, the UK Corporate Governance Code receives the value 1 for "separation chairman/CEO".

The Italian code is different in several respects. First, it is phrased in more ambiguous terms. The concentration of the roles of chairman and CEO is not prohibited, but the code holds that it is "appropriate" to avoid it. Code Principle 2.P.5 and Criteria 2.C.3 envisage a situation where the company decides not to separate the two offices. However, they intend to ensure transparency and the 
existence of an appropriate counterweight in the form of a "lead independent director" in case the same person acts as CEO and chairman. Finally, the comments, which are included in the code to clarify the principles and criteria, explicitly acknowledge that the accumulation of the roles of chairman and CEO may be beneficial and satisfy "valuable organizational requirements". Is this a prohibition of the concentration of corporate offices that warrants quantifying the Italian code pursuant to the upper bound of the definition of element (4) (the roles of CEO and chairman must not be exercised by the same individual)? Arguably, it is a prohibition because companies must give reasons in the corporate governance report if they concentrate the offices, which is in line with the essence of corporate governance codes. However, the quality of the prohibition is different from that of the UK code. Clearly, this is a difference that cannot be captured by a simple binary metric and mechanical coding. At this point, the second, qualitative stage of coding becomes relevant.

The Italian code is an example for an ambivalent rule. It merely speaks of the "appropriateness" to separate the roles of chairman and CEO, but does not establish a clear precept by means of a deontic statement, and acknowledges the usefulness of combining the roles of chairman and CEO. Furthermore, it makes provision for the delegation of executive powers to the chairman within the framework of the code, i.e. the company is technically in compliance with the code if the offices are combined, even though transparency is required by virtue of the code. ${ }^{7}$ Therefore, it would be inappropriate to give the Italian code the same value as a code that prohibits the accumulation of the roles strictly and unambiguously, as the UK code. On the other hand, the code provides for two substitute mechanisms if management powers have been delegated to the chairman. The board has to disclose the reasons for this organisational choice in the corporate governance report, and it shall designate an independent director as lead independent director, who "represents a reference and coordination point for the requests and contributions of non-executive directors". ${ }^{8}$ Thus, the Italian code is also not comparable to corporate governance codes that fail to impose clear and unconditional precepts and do not provide

\footnotetext{
${ }^{7}$ Provision 2.P.5.

${ }^{8}$ Provision 2.C.4.
} 
for substitute mechanisms, for example codes that merely "encourage" the separation of offices. ${ }^{9}$ It stands between these two archetypical provisions - the UK rule and the "encouragement" formulation - and should accordingly receive a penalty reflecting this intermediate position. ${ }^{10}$ This example shows that the coding even of provisions pursuing supposedly simple regulatory goals can involve difficult questions of interpretation. Only a detailed and transparent interpretation of norms, following commonly accepted canons of construction, can resolve such ambiguities.

\subsection{Model specification}

Proportional hazard models are a widely used method to estimate the rate of diffusion of innovations as a function of a set of predictors, including the diffusion of "regulatory" innovations. For example, Ramirez et al. (1997) apply event history analysis to the spread of women's suffrage rights and Wotipka and Ramirez (2008) to the ratification of international treaties. This article is concerned with a similar diffusion phenomenon, the spread of corporate governance institutions over time among standard setters based in different countries. An appropriate event history method is the Cox regression model, which has the advantage of not requiring any distributional assumptions, only the assumption that the effect of predictors, in principle, is constant over analysis time (proportionality assumption). A Cox regression estimates the function

$$
h\left(t_{i j}\right)=h_{0}\left(t_{j}\right) e^{\beta X_{i j}}
$$

where $h\left(t_{i j}\right)$ is the hazard that individual $i$ will experience the event at time $t_{j} ; h_{0}\left(t_{j}\right)$ denotes the baseline hazard, i.e. the hazard when all predictors are 0 ; and $X_{i j}$ is a vector of covariates, which are allowed to vary between individuals and over time. Here, in order to test the three hypotheses formulated above, three sets of predictors are included as covariates: diffusion, ownership and legal origins variables. The diffusion variables were described in Section 3.1 above. I have ownership data

\footnotetext{
${ }^{9}$ See, for example, the Greek Corporate Governance Code 1999, s. 5.5, providing that "[ $\left.\mathrm{t}\right]$ he separation of duties and responsibilities in the highest levels of the corporation's governance should be encouraged".

${ }^{10}$ See Appendix B, note 181 .
} 
on shareholdings by foreign investors and domestic institutional investors as a percentage of total equity of listed companies for most country/year combinations when corporate governance codes were adopted. Historical ownership data on the size of the largest voting blocks is fragmentary and not always comparable across countries. Therefore, in order to measure ownership concentration, I include a dummy variable that equals 1 if the median largest voting block is equal to or larger than the median value of all countries in the sample according to the most contemporaneous data available. Legal origins distinguish between the four legal families common law, German, French and Scandinavian legal origins. As additional controls, I create dummy variables that distinguish between one-tier and two-tier board systems, jurisdictions that require employee representation at board level, and the adoption of codes before and after two major corporate governance reforms entered into force that could have had an impact on the activities of standard setters: the Sarbanes-Oxley Act in the United States in 2002 and Commission Recommendation 2005/162/EC in the EU in 2006. ${ }^{11}$

The relevant event is defined in two alternative ways. In the first specification of the model, it is the adoption of a rule that corresponds to the benchmark formulation of the six elements of board structure given in Table 1.A. Since it is quite common that corporate governance codes are ambivalent or in other ways fall short of the formulation of the six components of board structure that is used for coding, the dichotomous indicator scores one if the code provision takes a value of at least 0.75 . Once the event occurs, the code issuer no longer contributes to the risk set. In the second specification, subjects can experience recurrent events, which are defined, for each component of board structure, as an increase in the value of the respective variable compared to the previous code adopted by the same issuer. ${ }^{12}$ In both models, code issuers were right censored if they had not experienced the event by the end of $2012 .{ }^{13}$

\footnotetext{
${ }^{11}$ See Appendix C.2 for summary statistics of legal origins and the additional controls.

12 Alternatively, the model could also be estimated with "regulatory innovation" defined as a negative, rather than positive change in the variable. However, such changes are very rare in the dataset, with seven changes in the case of "board committees", five in the case of "definition of independence", and 2-4 in the remaining cases. For this reason, an event history analysis of negative regulatory innovations is not pursued further.

${ }^{13}$ Time is recorded in months, since it was in all cases possible to determine the publication of the code at least by year and month.
} 
A problem frequently discussed in the diffusion literature is the interdependence between different actors that consider whether to adopt an innovation (so-called Galton's problem). Unless it can be assumed that the actors are influenced solely by factors that relate to the inherent characteristics of the innovation and the problem it is intended to address, rather than the decisions of others (Braun and Gilardi, 2006), models need to take account of possible relationships of mutual influence between actors. In statistical terms, failure to do so might result in an omitted variable bias. Jahn (2006) gives an overview of the solutions to this problem that have been developed in the literature. Here, we are particularly interested in the reaction of standard setters to the degree of international diffusion that a best practice rule has already achieved. In other words, the goal is to examine specifically the effect of a factor that is not related to corporate governance problems faced by the legal system in question, but captures the process of diffusion itself. Therefore, I model the hazard rate of adoption of a best practice rule as a function of prior adoptions of the same rule by other standard setters.

Two further considerations are important for a correct specification of the model. It is possible that the influence of the international spread of corporate governance innovations is not linear. For example, the probability that a corporate governance committee adopts a foreign regulatory innovation may increase initially as the innovation gains international acceptance. However, once it has become widely known because it has been adopted by a sufficient number of countries, say six or seven out of the sample of 23, the marginal effect of each additional adoption may be decreasing. The effect of diffusion would therefore resemble the well-known S-shaped form of other diffusion processes (Rogers, 2003). Intuitively, it could be said that the corporate governance committee has had the opportunity to consider the adoption of the rule and decided that it was not suitable, given the country's economic situation, legal system, or other reasons. In that case, it is maybe still possible, but less likely that the further spread of the regulatory innovation will prompt the committee to change its mind.

Similarly, it is possible that the effect of the international spread of a regulatory innovation is not constant over time. Once an innovation has been pioneered by one country, it can be expected that corporate governance committees in other countries, especially those belonging to the EU or EEA and, consequently, being in fairly constant exchange, discuss the innovation and decide relatively quickly 
whether to adopt it or not. If this is correct, we would expect to see the adoption of regulatory innovations, once they have been promulgated by the forerunners in the corporate governance movement, by committees set up in other countries during the first years of their existence. As time passes after the establishment of the committee, it may become less likely that they will revisit wellknown questions and adopt corporate governance institutions with a considerable delay. Thus, the impact of the diffusion of regulatory innovations may decrease over time while a committee is in existence and deals with rule changes.

In order to investigate these possibilities, I compute the martingale residuals for a null model to examine the functional form of the continuous predictors. The residuals indicate that the diffusion predictors are not linear, whereas a plot of the residuals against the other continuous predictors does not show any discernible pattern. Second, I test the proportionality assumption both graphically by examining the scaled Schoenfeld residuals and log cumulative hazard functions, and by regressing the Schoenfeld residuals on time. I do not reject the proportionality assumption, except in one model: the effect of the diffusion of the benchmark definition of independence is not constant, but rather decreases over time. These findings suggest that a quadratic term, "diffusion squared", needs to be included in the equations assessing benchmark rules regarding the number of non-executive directors, independent directors, the separation of chairman and CEO, and board committees, and an interaction term with time in the equation dealing with the diffusion of the benchmark formulation of independence. ${ }^{14}$

\section{Diffusion of Best Practice Standards}

\subsection{Descriptive Statistics}

This section explores how new corporate governance institutions spread from one country to another. The data allow us to identify when and where a regulatory innovation was introduced for the first time

\footnotetext{
${ }^{14}$ I do not model the diffusion of "Cooling-off period" since the benchmark rule has not been adopted by more than a few countries (see infra note 15).
} 
and which code issuers adopted it subsequently. Panel A of Table 3 reports the year of adoption of the first corporate governance code of each issuer and the year of adoption of rules satisfying the benchmark definition for the six elements of board structure regulation. ${ }^{15}$ Panel B summarises the difference in years between the adoption of the first corporate governance code in Europe and the first code of each of the other 22 code issuers, as well as the rate of diffusion of corporate governance innovations, measured as the number of years between the promulgation of the first rule satisfying the benchmark definition and the adoption of benchmark rules by other issuers. Panel $\mathrm{C}$ reports the percentage of code issuers from the sample that had adopted a corporate governance code and benchmark rules within 315 years after the first corporate governance initiative (Cadbury) and the first formulation of the respective benchmark rules.

$<$ Table 3 about here>

The first countries to promote corporate governance initiatives were the United Kingdom with the Cadbury Report of 1992 and France with the Viénot I Report of 1995. These reports initiated a development that led to the publication of reports and recommendations on good governance in other countries, notably the Peters Report in the Netherlands (1997), the Olivencia Report in Spain (1998), and the Cardon Report in Belgium (1998). In the following years, the corporate governance movement gathered momentum, and by 2002, 17 European countries had adopted codes of good governance. The pioneering position of the countries that produced the first reports is reflected in the fact that they were usually also the first to provide for rules meeting the benchmark definition of what is regarded as effective board structure regulation. They did so not necessarily in the first corporate governance codes published, but they continued to be at the forefront of the corporate governance movement and influenced its development through regular revisions of their standards of good governance.

15 The benchmark definition is that of "Adoption of benchmark rule" as defined supra in Table 1 for all components of the board structure variable except "Cooling-off period", for which I use a benchmark value of 0.5. The higher benchmark (a value of 0.75 or higher for the regulatory variable) is only met by three code issuers (the Netherlands and the UK in 2003 and Slovenia in 2005). The 0.5 benchmark, therefore, contains more informational value for the diffusion of this institution. 
Panel B shows that with one exception - the number of independent directors - other countries began to adopt rules largely comparable to the benchmark formulations of the six institutions regulating board structure quickly after the forerunner country promulgated the rule, one to three years after the initial innovation. The innovation then spread to other countries in the sample over the next four to seven years on average. The reason for the significant time lag in the spread of the independent directors requirement was that only the UK codes placed emphasis on independence early on, while other early influential reports, for example the French Viénot I Report and the Spanish Olivencia Report, were more sceptical. It was felt that independence in the Anglo-American sense was not entirely appropriate, given the limited experience of companies with the concept of independent directors and the more concentrated ownership structure prevalent in France, Spain, and other countries.

Panel C shows that the diffusion of the six components of board structure regulation has not been equally pervasive. The requirements to have a strong presence of non-executive directors on the board, separate the roles of chairman and CEO, and establish board committees are by now widely accepted and have been adopted by about two-thirds of the countries in the sample. On the other hand, independence is a more controversial concept, which may explain why the adoption rate is lower. Finally, even in countries that usually have a high compliance rate with corporate governance recommendations, for example the UK, it is contested whether outgoing CEOs should be prohibited from becoming chairman of the board of directors (Davies and Worthington, 2016, 14-75), and many codes in the sample do not even mention the issue.

\subsection{Survival Analysis}

This section examine the association of each predictor, in the case of the diffusion variables together with the corresponding quadratic term and, where appropriate, together with interaction terms with time, with the adoption of benchmark rules. Table 4 reports the regression results.

$<$ Table 4 about here> 
The results show that the diffusion of benchmark rules, i.e. the number of corporate governance codes containing a provision that satisfies the benchmark formulation of the relevant element of board structure, is positively associated with the subsequent adoption of a corresponding benchmark rule by the response code. For each additional corporate governance code satisfying the benchmark formulation, the odds of adoption of a similar provision increase by a factor of between 1.7 and 3.2. The association is statistically significant at the 5 or 1 percent level for all analysed components of board structure except "Non-executive directors". Further, the results show that the marginal effect of the diffusion of a regulatory innovation decreases as the innovation spreads and is adopted by additional code issuers, and that the diffusion effect decreases over time in the case of equation (3).

Ownership structure is generally not statistically significantly associated with the analysed event, with the exception of "Concentrated ownership structure" in equations (1) and (3), where we find a significant negative relationship. The fact that an economy is characterised by concentrated ownership cuts the odds of adopting a rule requiring at least half of the board members to be non-executive directors and a rule satisfying the benchmark formulation of independence by the large factor of about 4, compared with a country where shareholders are dispersed. Likewise, the coefficients on legal origins are generally not statistically significant, except in equation (2), where I find an economically large negative association with the German and French legal families.

In Table 5, I add the three sets of predictors in several steps to examine their multivariate effect. The regressions confirm the findings from the univariate model. The strongest explanatory factor of the adoption of a benchmark formulation of best practice standards is the diffusion of that formulation. With the exception of the first element of board structure regulation, "Non-executive directors", the diffusion of benchmark rules is positively and statistically significantly associated with the subsequent adoption of a corresponding rule by another code issuer. Each additional benchmark code in force increases the odds that the dependent code will emulate the benchmark formulation by a factor of between 1.7 and 3.4. The effect of concentrated ownership structure is again strongly negative and statistically significant in models examining the first three board structure elements (equations (1)-(5)). These results are robust to the inclusion of different sets of covariates and further control variables 
distinguishing between jurisdictions following the one-tier and two-tier board models, requiring employee representation at board level, and codes adopted before and after the Sarbanes-Oxley Act and Commission Recommendation 2005/162/EC entered into force. ${ }^{16}$ The likelihood ratio tests at the bottom of Table 5 indicate that the addition of the diffusion variables improves the fit of the model significantly in all equations except the first and the addition of the ownership variables leads to an improvement in models dealing with the first three elements of board structure. The regression analysis therefore provides statistically significant evidence in support of Hypothesis 1 and, for the first three elements of board structure, Hypothesis 2c, but only limited evidence in support of Hypothesis 3a and no evidence in support of Hypothesis $2 \mathrm{a}, 2 \mathrm{~b}$ or $3 \mathrm{~b}$.

\section{$<$ Table 5 about here>}

The effect of the diffusion and concentrated ownership predictors can be illustrated with plots of survivor and hazard functions. I use equation (3) of Table 5 to show how concentrated ownership structure and the spread of benchmark rules shift the odds of adopting a rule that requires a majority of non-executive directors to be independent. First consider Figure 1, which plots survivor functions for code issuers operating in a concentrated ownership economy (Blockholding=1), and in an economy where shareholders are comparatively widely dispersed (Blockholding=0), with the other predictors evaluated at the mean. In concentrated ownership economies the odds of survival, i.e. the odds that code issuers do not require a majority of non-executive directors to be independent, is significantly higher over the whole period of analysis time. In fact, the survival probability never falls below 0.66 , indicating that the clear majority of blockholder economies are unlikely ever to adopt this element of board structure regulation in its most stringent form. In dispersed shareholder economies, on the other hand, a considerable number of code issuers emulate the benchmark definition already in the first code issued, which is borne out by the relatively low initial survival probability of 0.56 . Median lifetime is only 3 years and 1 month, and by the end of analysis time the survival probability has fallen to 0.21 .

\footnotetext{
${ }^{16}$ Results are here omitted.
} 
$<$ Figures 1 and 2 about here>

Figure 2 plots the smoothed hazard function, again based on equation (3) of Table 5. It depicts, first, how hazard changes over time. The "risk" of adoption of the benchmark rule is relatively high in the beginning of a corporate governance committee's existence, as the committee reviews international formulations of corporate governance mechanisms and decides whether to adopt them. It then decreases slightly since committees will generally wait for a number of years before they begin with the revision of the code. The risk peaks in years 6 and 7 and then decreases steadily, implying that if committees decide not to emulate the international benchmark definition on occasion of the first few code revisions, they become increasingly less likely to do so later, presumably because they have become convinced that the benchmark definition is not suitable for their purposes. This mirrors the typical S-shaped form of the diffusion of technical innovations.

Second, the figure shows that the adoption of a rule requiring a majority of non-executive directors to be independent by one additional international code issuer shifts the hazard function upwards, while preserving the general evolution of the hazard over time. A similar shift can be observed for the other board structure elements.

I explore the impact of the diffusion of best practice standards further by examining when and how code issuers amend their corporate governance codes. For each element of board structure, I use the variable "regulatory innovation" as dichotomous indicator and add three sets of predictors as in the model from Table 5. Again, because the effect of the diffusion of benchmark rules is likely not linear, a quadratic term is included for each component of board structure. In contrast to the benchmark model, I do not find any evidence that the effect of the diffusion predictors (or any of the other predictors) changes over time. Interaction terms with time are therefore not added.

The results of Cox proportional hazards regressions confirm the above findings. Table C.3 (in the online appendix) shows that the odds that the corporate governance committee will amend the code in a way that reduces the distance to the benchmark formulation increase by a factor of between 1.2 and 2.2 for each additional code in force at the time of drafting of the response code that already includes a 
benchmark formulation of the corresponding component of board structure (offering evidence in support of Hypothesis 1). The diffusion effect decreases as additional code issuers follow the example of countries at the forefront of the corporate governance movement. I also find some evidence that code issuers are less likely to adopt more demanding rules if listed companies are predominantly owned by large blockholders (Hypothesis 2c).

\section{Discussion and conclusion}

The clearest finding that emerges from the analysis is the significant effect that the international diffusion of best practice standards has on the activities of standard setters. By controlling for certain channels of diffusion (different types of investors becoming more or less important in the corporate economy) and legal origins, the analysis suggests that the diffusion of international benchmark standards of good governance as such prompts standard setters to emulate these standards. Two interpretations of this finding are possible. Standard setters may seek to emulate benchmark standards for the simple reason that they have become internationally widely accepted. This account is in line with the legitimacy considerations examined, for example, by Aguilera and Cuervo-Cazurra (2004) and Zanetti and Cuomo (2008). It may be the case that standard setters respond to pressures to conform to international benchmark standards, irrespective of whether or not such standards are efficient in light of domestic ownership structures or regulatory mechanisms already in place elsewhere in the legal system. Accordingly, corporate governance codes would be used as a signal of the quality of a country's corporate governance system, rather than as a means of actually improving the system. To the extent that the ownership and legal origins variables used here are reliable proxies for relevant differences in ownership structure and legal environment, the findings provide some evidence that legitimation concerns indeed play a role.

On the other hand, it is clear that legal origins have limitations in capturing the detailed characteristics of a country's company law regime. In particular, the research design does not allow us to test the interaction between the efficiency of particular legal rules and best practice standards. Therefore, a possible alternative explanation of the significant effect of the diffusion of best practice 
standards is the following account. Standard setters may realise that certain standards address a deficiency in the domestic legal system that is not controlled for by legal origins because it varies within legal families. As a benchmark rule diffuses and is discussed more widely internationally, an increasing number of standard setters may appreciate that it constitutes an efficient response to the regulatory problem they face. Thus, standard setters may be motivated by efficiency considerations, either exclusively or in addition to legitimation concerns, in emulating standards of good governance.

The significant association between the diffusion of a benchmark rule and the subsequent adoption of that rule by additional standard setters holds for all components of board structure tested here save one: the number of non-executive directors. A possible explanation may be the fact that the requirement to have non-executive directors on the board is the least controversial element of board structure. Code issuers adopted rules satisfying the benchmark definition in short succession. Mean and median year of adoption is 2002 , earlier than with any other component. In any event, the direction and magnitude of the association, including the quadratic term, are in line with those found for the other components of board structure.

In contrast to the findings of Zanetti and Cuomo (2008), the empirical analysis does not provide any evidence in support of the hypothesis that stringent corporate governance rules are more likely to be adopted by common law countries than civil law countries. However, one exception is the negative association of German and French legal origins with the independent director recommendation (equation (2) in Table 4 and equation (4) in Table 5). This result, together with the finding that economies dominated by blockholder ownership are less likely to require a strong non-executive and independent element on the board (equations (1), (3) and (5) in Table 5 and (5) and (8) in Table C.3), raises the question whether civil law and blockholder economies act contrary to the efficiency rationale advanced in the diffusion literature. In blockholder economies, which include many German and French legal origin countries, the majority/minority-shareholder agency problem is particularly salient. An efficient regulatory response can be expected to focus on minority representation on the board and independence of the non-executive directors not only from management, but also from the blockholders. However, the analysis suggests that blockholder economies tend to require fewer independent directors 
to sit on the board and are less likely to adopt a definition of independence that is prescriptive and includes independence from the major shareholders. On the other hand, it is important to emphasise that this analysis is confined to best practice rules in a country's corporate governance code. Whether it is indeed an indication that standard setters in these economies seek to accommodate blockholders and disregard the interests of minority shareholders, possibly because the corporate insiders have sufficient political clout to influence the formulation of the corporate governance standards, is beyond the scope of this study. An alternative explanation may point to institutional complementarities and the substitutability of regulatory strategies. The lack of a stringent regulation in a corporate governance code may be efficient because of the existence of other legal or non-legal substitute mechanisms in the economy that protect investors.

The findings raise important questions for future research. The benchmark formulations used here to map diffusion were often pioneered by the UK. It is questionable whether they are equally effective and efficient in all regulatory settings, especially those where they constitute a foreign transplant not in line with traditional modes of regulation. Thus, the risk exists that the practice of emulating internationally emerging benchmark standards of good governance imposes additional regulatory burdens on issuers without generating commensurate benefits and may prove ultimately harmful to the corporate economy. In order to pursue this question further, investigate which best practice standards, if any, give rise to inefficiencies, and distinguish between the legitimation and efficiency accounts mentioned above, it will be necessary to analyse the interaction between best practice standards and a country's company and capital markets laws at a granular level that takes account of differences in individual legal mechanisms between and within legal families. 


\section{References}

Adams, R.B., B.E. Hermalin and M.S. Weisbach (2010), 'The Role of Boards of Directors in Corporate Governance: A Conceptual Framework and Survey', Journal of Economic Literature, 48(1): 58-107.

Aguilera, R.V., and A. Cuervo-Cazurra (2004), 'Codes of Good Governance Worldwide: What is the Trigger?', Organization Studies, 25(3): 417-445.

Aguilera, R.V., and A. Cuervo-Cazurra (2009), 'Codes of Good Governance', Corporate Governance: An International Review, 17(3): 376-387.

Armour, J., S. Deakin, P. Lele and M. Siems (2009a), 'How do legal rules evolve? Evidence from a cross-country comparison of shareholder, creditor, and worker protection', American Journal of Comparative Law, 57(3): 579-629.

Armour, J., S. Deakin, V. Mollica and M. Siems (2009b), 'Law and Financial Development: What We are Learning from Time Series Evidence', Brigham Young University Law Review, 2009(6): 1435-1500.

Armstrong, C.S., J.E. Core and W.R. Guay (2014), 'Do Independent Directors Cause Improvements in Firm Transparency?', Journal of Financial Economics, 113(3): 383403.

Barca, F., and M. Becht (2001), The Control of Corporate Europe, Oxford and New York: Oxford University Press.

Berglöf, E., and A. Pajuste (2003), 'Emerging Owners, Eclipsing Markets? Corporate Governance in Central and Eastern Europe', in P. Cornelius and B.M. Kogut (eds.), Corporate Governance and Capital Flows in a Global Economy, New York: Oxford University Press, pp. 267-302. 
Braun, D. and F. Gilardi (2006), 'Taking “Galton's Problem” Seriously: Towards a Theory of Policy Diffusion', Journal of Theoretical Politics, 18(3):298-322.

Burns, L.R., and D.R. Wholey (1993), 'Adoption and Abandonment of Matrix Management Programs: Effects of Organizational Characteristics and Interorganizational Networks', Academy of Management Journal, 36(1): 106-138.

Canon, B.C., and L. Baum (1981), 'Patterns of Adoption of Tort Law Innovations: An Application of Diffusion Theory to Judicial Doctrines', American Political Science Review, 75(4): 975-87.

Cools, S. (2005), 'The Real Difference in Corporate Law between the United States and Continental Europe: Distribution of Powers', Delaware Journal of Corporate Law, 30(3): 697-766.

Davies, P., and S. Worthington (2016), Gower's Principles of Modern Company Law, 10th ed., London: Sweet \& Maxwell.

Djankov, S., R. La Porta, F. Lopez-de-Silanes and A. Shleifer (2008), 'The law and economics of self-dealing', Journal of Financial Economics, 88(3): 430-465.

Epstein, L., and A.D. Martin (2010), 'Quantitative Approaches to Empirical Legal Research', in P. Cane and H.M. Kritzer (eds.), Oxford Handbook of Empirical Legal Research, Oxford and New York: Oxford University Press, pp. 902-925.

Faccio, M., and L.H.P. Lang (2002), 'The ultimate ownership of Western European Corporations', Journal of Financial Economics, 65(3): 365-395.

Ferreira, M.A., and P. Matos (2008), 'The colors of investors' money: The role of institutional investors around the world', Journal of Financial Economics, 88(3): 499-533.

Gerner-Beuerle, C., and E.P. Schuster (2014), 'The Evolving Structure of Directors' Duties in Europe', European Business Organization Law Review, 15(2): 191-233. 
Gompers, P.A., J.L. Ishii and A. Metrick (2003), 'Corporate Governance and Equity Prices', Quarterly Journal of Economics, 118(1): 107-155.

Gilson, R.J., and J.N. Gordon (2013), 'The Agency Costs of Agency Capitalism Activist Investors and the Revaluation of Governance Rights', Columbia Law Review, 113(4): 863-927.

Davis, G.F., and H.R. Greve (1997), 'Corporate elite networks and governance changes in the 1980s', American Journal of Sociology, 103(1): 1-37.

Graham, E.R., C.R. Shipan and C. Volden (2013), 'The Diffusion of Policy Diffusion Research in Political Science', British Journal of Political Science, 43(3): 673-701.

Jahn, D. (2006), 'Globalization as Galton's Problem: The Missing Link in the Analysis of the Diffusion Patterns in Welfare State Development', International Organization, 60(2): 401-431.

Kahan, M., and E. Rock (2010), 'Embattled CEOs', Texas Law Review, 88(5): 987-1052.

La Porta, R., F. Lopez-de-Silanes, A. Shleifer and R. Vishny (1997), 'Legal Determinants of External Finance', Journal of Finance, 52(3): 1131-1150.

La Porta, R., F. Lopez-de-Silanes, A. Shleifer and R. Vishny (1998), 'Law and Finance', Journal of Political Economy, 106(6): 1113-1155.

La Porta, R., F. Lopez-de-Silanes, A. Shleifer and R. Vishny (2000), 'Investor protection and corporate governance', Journal of Financial Economics, 58(1): 3-27.

Mallin, C.A. (2015), Corporate Governance, 5th ed., Oxford: Oxford University Press.

Michaels, R. (2009), 'Comparative Law by Numbers? Legal Origins Thesis, Doing Business Reports, and the Silence of Traditional Comparative Law', American Journal of Comparative Law, 57(4): 765-795 
Ramirez, F.O., Y. Soysal and S. Shanahan (1997), 'The Changing Logic of Political Citizenship: Cross-National Acquisition of Women's Suffrage Rights, 1890 to 1900', American Sociological Review, 62(5): 735-45.

Rogers, E.M (2003), Diffusion of Innovations, 5th ed., New York: Free Press.

Siems, M. (2005a), 'What does not work in comparing securities laws: A critique on La Porta et al.'s methodology', International Company and Commercial Law Review, 16(7): 300-305.

Siems, M. (2005b), 'Numerical comparative law: Do we need statistical evidence in law in order to reduce complexity?', Cardozo Journal of International \& Comparative Law, 13(2): 521-540.

Siems, M. (2007), 'Legal Origins: Reconciling Law \& Finance and Comparative Law', McGill Law Journal, 52(1): 55-81.

Spamann, H. (2006), 'On the Insignificance and/or Endogeneity of La Porta et al.'s “AntiDirector Rights Index" under Consistent Coding', ECGI - Law Working Paper No. 67/2006, May 2006.

Spamann, H. (2009a), 'The “Antidirector Rights Index” Revisited', Review of Financial Studies, 23(2): 467-486.

Spamann, H. (2009b), 'Large-Sample, Quantitative Research Designs for Comparative Law?', American Journal of Comparative Law, 57(4): 797-810.

Strang, D. and S.A. Soule (1998), 'Diffusion in Organizations and Social Movements: From Hybrid Corn to Poison Pills', Annual Review of Sociology, 24:265-290.

Twining, W. (2005), 'Social Science and Diffusion of Law', Journal of Law and Society, 32(2): 203-240. 
Wotipka, C.M., and F.O. Ramirez (2008), 'World Society and Human Rights', in B.A. Simmons, F. Dobbin, and G. Garrett (eds.), The Global Diffusion of Markets and Democracy, Cambridge and New York: Cambridge University Press, pp. 303-343.

Zanetti, A., and F. Cuomo (2008), 'Why Adopt Codes of Good Governance? A Comparison of Institutional and Efficiency Perspectives', Corporate Governance: An International Review, 16(1): 1-15. 
Figure 1. Survivor function: adoption of benchmark rule number of independent directors

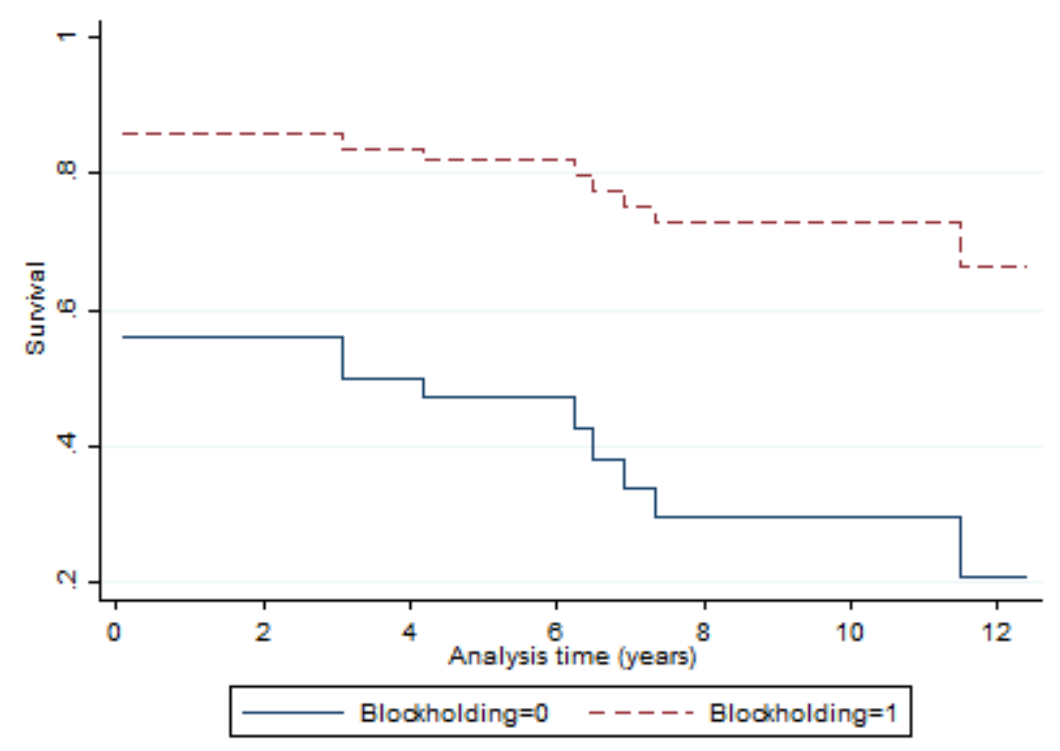

Figure 2. Kernel smoothed estimate of hazard function: adoption of benchmark rule number of independent directors

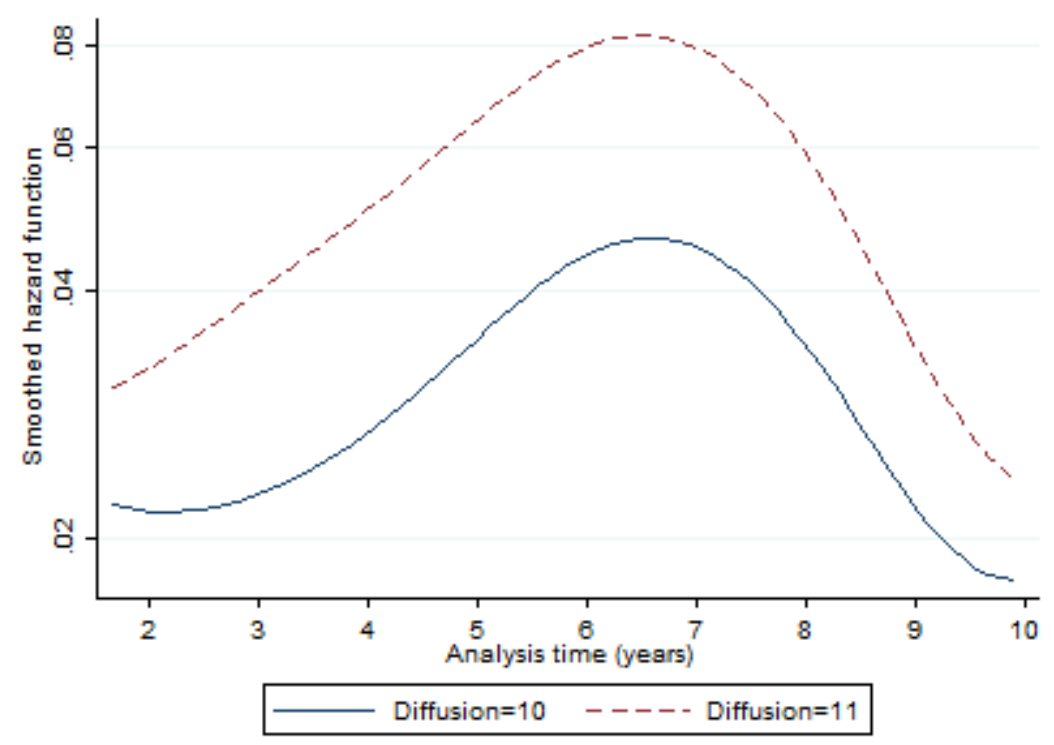


Table 1. Description of the variables

Variable Description

A. Regulatory variables

Non-executive directors

$=1$ if at least half of the board members must be non-

executive directors; $=0.5$ if less than half, but a specified number or proportion of members must be non-executive directors; $=0$ otherwise (not coded for legal systems where the two-tier board model is predominant)

Number independent $=1$ if a majority of the non-executive directors must be directors independent $;=0.5$ if less than a majority, but a specified number or proportion of directors must be independent $;=0$ otherwise

Definition of independence

Index ranging from 0 to 1 and aggregating 10 requirements that directors must satisfy to be considered as independent (see Appendix A.1 for details). If the corporate governance code contains only a general definition of independence (for example that directors should not have any 'business or personal relationships' with the company) and does not provide for a list of independence criteria, the variable takes the value 0.3 .

Separation chairman/CEO

$=1$ if the roles of CEO and chairman must not be exercised by the same individual; $=0$ otherwise (not coded for legal systems where the two-tier board model is predominant)

Cooling-off period $=1$ if the $\mathrm{CEO}$ should not go on to be chairman of the board for a period of at least three years after stepping down as $\mathrm{CEO} ;=0.5$ if the waiting period is one or two years; $=0$ otherwise

Nomination, audit and remuneration committee

For each committee $=1$ if a committee composed of a majority of independent non-executive directors must be established; $=0.5$ if a committee must be established, but it does not need to be composed of a majority of independent non-executive directors; $=0$ otherwise; total value is the mean of the score for the three committees

Board structure

Mean of the above six variables (for countries with a twotier board model, 'Non-executive directors' and 'Separation chairman/CEO' are excluded)

Legal origins

Dummy variable that classifies national company laws as belonging either to common law, the German, French, or Scandinavian legal family (see Appendix C)

B. Diffusion variables

Adoption of benchmark rule

$=1$ for each component of the board structure variable ('Non-executive directors', 'Number independent directors', 'Definition of independence', 'Separation chairman/CEO', 'Cooling-off period', and 'Board committees') if the value of the respective component variable is equal to or greater than $0.75 ;=0$ otherwise 
Regulatory innovation $=1$ if the code contains a regulatory innovation, which is defined, for each component of the board structure variable, as an increase in the value of the respective variable compared to the previous code adopted by the same issuer. If a previous code does not exist, regulatory innovation is defined as any value greater than 0 , with the exception of 'Definition of independence' and 'Board committees', in which case the variable must be equal to or greater than 0.3 (i.e. the code must contain at least a general definition of independence and require the establishment of two committees, respectively). Innovation $=0$ if the regulation does not change compared to the previous code or if the value decreases. If the component variable reaches the value 1 , the code is ignored in subsequent years, unless it drops again below 1 .

Diffusion

Number of codes in force in the relevant year (for codes adopted until June, this is the year before adoption of the code, for codes adopted after June this is the year of adoption, which is assumed to be the year of drafting) satisfying the benchmark definition for each of the six components of the board structure variable as defined above ('Adoption of benchmark rule')

Diffusion $^{2} \quad$ Diffusion squared

C. Ownership variables

Ownership foreign

Shareholding by foreign investors as a percentage of total equity of listed companies on the country's main stock exchange. For corporate governance codes adopted until June, data are for the year before adoption of the code, for codes adopted after June data are for the year of adoption, which is assumed to be the year of drafting. Source: Eurostat, IMF (CPIS), national stock exchange data, IODS calculations for this study.

Ownership financial institutions

Shareholding by institutional investors (domestic banks, insurance \& pension funds, investment companies, mutual funds) as a percentage of total equity of listed companies on the country's main stock exchange. Year of measurement and sources as for 'Ownership foreign'.

Concentrated ownership structure

Dummy variable $=1$ if the economy is characterized by concentrated ownership structure, which is defined as a median largest voting block equal to or greater than 0.44 , the median of the countries from the sample for which detailed data on the largest voting block are available. Data for Austria, Belgium, Finland, France, Germany, Italy, Norway, Portugal, Spain, Sweden, Switzerland, and UK are from Faccio and Lang (2002); data for the Netherlands from Barca and Becht (2001); data for Bulgaria, Hungary, Poland, and the Slovak Republic from Berglöf and Pajuste (2003). For the other countries, the assessment is based on ownership data from BvD Orbis and Capital IQ. 
Table 2. Summary statistics

Panel A. Summary statistics of board structure and ownership variables

'Board structure' is based on the mean of the scores for the six elements of board structure received by the codes in the sample. The other rows report summary statistics for the six individual elements of board structure as well as the ownership variables.

\begin{tabular}{|c|c|c|c|c|c|c|}
\hline & Obs. & Mean & Median & Min. & Max. & $\mathrm{SD}$ \\
\hline Board structure & 106 & 0.492 & 0.48 & 0.013 & 0.925 & 0.24 \\
\hline Executive/non-exec. (EXD) & 64 & 0.63 & 0.75 & 0 & 1 & 0.38 \\
\hline $\begin{array}{l}\text { No. independent directors } \\
\text { (NO-IND) }\end{array}$ & 103 & 0.56 & 0.5 & 0 & 1 & 0.41 \\
\hline $\begin{array}{l}\text { Definition of independence } \\
\text { (DEF-IND) }\end{array}$ & 102 & 0.48 & 0.4 & 0 & 1 & 0.27 \\
\hline $\begin{array}{l}\text { Separation chairman/CEO } \\
\text { (SEP) }\end{array}$ & 69 & 0.62 & 0.75 & 0 & 1 & 0.41 \\
\hline $\begin{array}{l}\text { Cooling-off period } \\
\text { (COOL) }\end{array}$ & 105 & 0.17 & 0 & 0 & 1 & 0.31 \\
\hline $\begin{array}{l}\text { Committee structure } \\
(\mathrm{COM})\end{array}$ & 106 & 0.62 & 0.67 & 0 & 1 & 0.32 \\
\hline Ownership foreign & 104 & 0.36 & 0.36 & 0.038 & 0.889 & 0.16 \\
\hline $\begin{array}{l}\text { Ownership financial } \\
\text { institutions }\end{array}$ & 104 & 0.19 & 0.17 & 0.02 & 0.61 & 0.11 \\
\hline Concentrated ownership & 106 & 0.54 & 1 & 0 & 1 & 0.50 \\
\hline
\end{tabular}

Panel B. Pairwise correlation of elements of board structure regulation

\begin{tabular}{lcccccc}
\hline & EXD & NO-IND & DEF-IND & SEP & COOL & COM \\
\hline EXD & 1 & & & & & \\
NO-IND & 0.558 & 1 & & & & \\
DEF-IND & 0.548 & 0.506 & 1 & & & \\
SEP & 0.275 & 0.456 & 0.535 & 1 & & \\
COOL & 0.141 & 0.191 & 0.171 & 0.27 & 1 & \\
COM & 0.648 & 0.576 & 0.452 & 0.42 & 0.183 & 1 \\
\hline
\end{tabular}


Panel C. Number of codes and governance variables by country (mean values)

\begin{tabular}{lllllllll}
\hline Country & N & $\begin{array}{l}\text { Board } \\
\text { structure }\end{array}$ & EXD & $\begin{array}{l}\text { NO- } \\
\text { IND }\end{array}$ & $\begin{array}{l}\text { DEF- } \\
\text { IND }\end{array}$ & SEP & COOL & COM \\
\hline Austria & 6 & 0.45 & & 0.50 & 0.29 & & 0.33 & 0.67 \\
Belgium & 4 & 0.45 & 0.75 & 0.25 & 0.55 & 0.50 & 0 & 0.65 \\
Bulgaria & 2 & 0.21 & 0 & 0 & 0.10 & 1 & 0 & 0.17 \\
Cyprus & 4 & 0.62 & 0.63 & 1 & 0.52 & 0.75 & 0 & 0.83 \\
Denmark & 6 & 0.57 & & 1 & 0.67 & 0.67 & 0 & 0.50 \\
Finland & 3 & 0.75 & 1 & 1 & 0.63 & 1 & 0 & 0.89 \\
France AFG & 5 & 0.49 & 0.50 & 0.50 & 0.65 & 0.60 & 0 & 0.67 \\
France & 6 & 0.45 & 0.67 & 0.67 & 0.40 & 0 & 0 & 0.83 \\
MEDEF & & & & & & & & \\
Germany & 11 & 0.21 & & 0 & 0.30 & & 0.25 & 0.28 \\
Greece & 3 & 0.35 & 0.58 & 0.33 & 0.40 & 0.25 & 0.08 & 0.47 \\
Hungary & 4 & 0.66 & & 1 & 0.30 & & 0.38 & 0.91 \\
Italy & 4 & 0.25 & 0 & 0.13 & 0.33 & 0.38 & 0 & 0.65 \\
Luxembourg & 2 & 0.30 & 0 & 0 & 0.30 & 1 & 0 & 0.50 \\
Malta & 2 & 0.40 & 0.25 & 0.50 & 0.30 & 0.88 & 0 & 0.48 \\
Netherlands & 3 & 0.68 & & 0.67 & 0.57 & & 0.83 & 0.67 \\
Norway & 8 & 0.74 & 1 & 0.81 & 0.70 & 1 & 0 & 0.92 \\
Poland & 6 & 0.33 & & 0.50 & 0.68 & & 0 & 0.13 \\
Portugal & 4 & 0.24 & 0.25 & 0.31 & 0.18 & 0.25 & 0 & 0.44 \\
Slovakia & 2 & 0.59 & & 0.75 & 0.36 & & 0.25 & 1 \\
Slovenia & 4 & 0.65 & & 0.88 & 0.67 & & 0.63 & 0.44 \\
Spain & 4 & 0.47 & 0.88 & 0.44 & 0.55 & 0.31 & 0 & 0.63 \\
Sweden & 4 & 0.76 & 1 & 1 & 0.53 & 1 & 0.13 & 0.83 \\
Switzerland & 2 & 0.34 & 1 & 0 & 0.30 & 0 & 0 & 0.75 \\
UK & 7 & 0.77 & 0.61 & 1 & 0.62 & 0.82 & 0.71 & 0.86 \\
\hline
\end{tabular}


Table 3. Diffusion of regulatory innovations: descriptive statistics

Panel A. Year of adoption

\begin{tabular}{llllll}
\hline & N & Min. & Median & Max. & SD \\
\hline Adoption of first code & 24 & 1992 & 2001 & 2007 & 3.41 \\
Non-executive directors & 10 & 1998 & 2002 & 2009 & 3.28 \\
$\begin{array}{l}\text { Number independent } \\
\text { directors }\end{array}$ & 15 & 1992 & 2003 & 2011 & 4.25 \\
Definition of & 9 & 2003 & 2007 & 2011 & 2.98 \\
independence & & & & & \\
Separation chairman/CEO & 13 & 1998 & 2004 & 2010 & 3.50 \\
Cooling-off period & 8 & 1997 & 2005 & 2008 & 3.59 \\
Board committees & 17 & 2002 & 2004 & 2011 & 3.15 \\
\hline
\end{tabular}

Panel B. Years since first initiative

\begin{tabular}{llllll}
\hline & Min. & Mean & Median & Max. & SD \\
\hline $\begin{array}{l}\text { Corporate governance } \\
\text { code }\end{array}$ & 3 & 9.04 & 9 & 15 & 2.93 \\
$\begin{array}{l}\text { Non-executive directors } \\
\begin{array}{l}\text { Number independent } \\
\text { directors }\end{array}\end{array}$ & 1 & 4.88 & 4.50 & 11 & 2.90 \\
$\begin{array}{l}\text { Definition of } \\
\text { independence }\end{array}$ & 1 & 12.12 & 11.50 & 19 & 2.98 \\
Separation chairman/CEO & 3 & 4.38 & 5.00 & 8 & 2.77 \\
$\begin{array}{l}\text { Cooling-off period } \\
\text { Board committees }\end{array}$ & 3 & 6.83 & 6.00 & 12 & 3.07 \\
Average board structure & 1 & 7 & 7 & 10 & 2.38 \\
\hline
\end{tabular}

Panel C. Percentage of countries in the sample having adopted the code/rule

\begin{tabular}{|c|c|c|c|c|c|}
\hline & $\begin{array}{l}\text { After } 3 \\
\text { years }\end{array}$ & $\begin{array}{l}\text { After } 6 \\
\text { years }\end{array}$ & $\begin{array}{l}\text { After } 9 \\
\text { years }\end{array}$ & $\begin{array}{l}\text { After } 12 \\
\text { years }\end{array}$ & $\begin{array}{l}\text { After } 15 \\
\text { years }\end{array}$ \\
\hline Code & 0.08 & 0.25 & 0.54 & 0.92 & 1 \\
\hline Non-executive directors & 0.19 & 0.44 & 0.50 & 0.56 & 0.63 \\
\hline $\begin{array}{l}\text { Number independent } \\
\text { directors }\end{array}$ & 0.04 & 0.04 & 0.13 & 0.46 & 0.48 \\
\hline $\begin{array}{l}\text { Definition of } \\
\text { independence- }\end{array}$ & 0.17 & 0.32 & 0.41 & - & - \\
\hline Separation chairman/CEO & 0.18 & 0.47 & 0.59 & 0.71 & 0.71 \\
\hline Cooling-off period & 0.04 & 0.13 & 0.21 & 0.25 & 0.25 \\
\hline Board committees & 0.46 & 0.50 & 0.67 & 0.67 & - \\
\hline
\end{tabular}


Table 4. Diffusion of regulatory innovations: univariate hazards model

The table reports estimation results of a Cox proportional hazards model, using Efron's approximation for ties. Equations (1) to (5) examine the univariate effect of the diffusion of the respective component of board structure ('Cooling-off period' is omitted because of the low number of events), as well as the univariate effect of ownership structure and legal origins on the adoption of a benchmark rule.

Predictors $\quad$ Event: adoption of benchmark rule

(1)

(2)

(3)

(4)

(5)

\begin{tabular}{|c|c|c|c|c|c|}
\hline $\begin{array}{l}\text { Diffusion non-executive } \\
\text { directors }\end{array}$ & $\begin{array}{l}1.738 \\
(1.28)\end{array}$ & & & & \\
\hline $\begin{array}{l}\text { Diffusion number } \\
\text { independent directors }\end{array}$ & & $\begin{array}{l}2.585^{* * * *} \\
(2.59)\end{array}$ & & & \\
\hline $\begin{array}{l}\text { Diffusion definition of } \\
\text { independence }\end{array}$ & & & $\begin{array}{c}3.123 * * \\
(1.99)\end{array}$ & & \\
\hline $\begin{array}{l}\text { Diffusion separation } \\
\text { chairman/CEO }\end{array}$ & & & & $\begin{array}{l}3.211 * * \\
(2.52)\end{array}$ & \\
\hline $\begin{array}{l}\text { Diffusion committee } \\
\text { structure }\end{array}$ & & & & & $\begin{array}{c}1.807 * * * \\
(2.68)\end{array}$ \\
\hline Diffusion $^{2}$ & $\begin{array}{c}0.940 \\
(-1.33)\end{array}$ & $\begin{array}{l}0.934 * * \\
(-2.55)\end{array}$ & & $\begin{array}{c}0.912 * * \\
(-2.24)\end{array}$ & $\begin{array}{c}0.962 * * * \\
(-2.82)\end{array}$ \\
\hline Interaction with time & & & $\begin{array}{l}0.988 * * \\
(-2.10)\end{array}$ & & \\
\hline Ownership foreign & $\begin{array}{c}0.948 \\
(-0.03)\end{array}$ & $\begin{array}{c}0.212 \\
(-0.78)\end{array}$ & $\begin{array}{l}0.006^{*} \\
(-1.73)\end{array}$ & $\begin{array}{l}3.184 \\
(0.55)\end{array}$ & $\begin{array}{l}2.327 \\
(0.56)\end{array}$ \\
\hline $\begin{array}{l}\text { Ownership financial } \\
\text { institutions }\end{array}$ & $\begin{array}{l}0.665 \\
(-0.16)\end{array}$ & $\begin{array}{l}23.53 \\
(1.29)\end{array}$ & $\begin{array}{l}40.03 \\
(1.42)\end{array}$ & $\begin{array}{c}0.216 \\
(-0.52)\end{array}$ & $\begin{array}{c}0.393 \\
(-0.41)\end{array}$ \\
\hline $\begin{array}{l}\text { Concentrated ownership } \\
\text { structure }\end{array}$ & $\begin{array}{l}0.252 * * \\
(-2.08)\end{array}$ & $\begin{array}{c}0.434 \\
(-1.58)\end{array}$ & $\begin{array}{c}0.235 * * \\
(-1.99)\end{array}$ & $\begin{array}{c}0.423 \\
(-1.43)\end{array}$ & $\begin{array}{l}0.446 \\
(-1.59)\end{array}$ \\
\hline Legal origins German & $\begin{array}{l}1.855 \\
(0.61)\end{array}$ & $\begin{array}{l}0.116^{* *} \\
(-2.50)\end{array}$ & $\begin{array}{c}0.485 \\
(-0.77)\end{array}$ & $\begin{array}{c}0.000 \\
(-0.00)\end{array}$ & $\begin{array}{l}1.084 \\
(0.10)\end{array}$ \\
\hline Legal origins French & $\begin{array}{c}0.884 \\
(-0.13)\end{array}$ & $\begin{array}{c}0.066^{* * * *} \\
(-2.89)\end{array}$ & $\begin{array}{c}0.365 \\
(-0.97)\end{array}$ & $\begin{array}{l}0.248 * \\
(-1.75)\end{array}$ & $\begin{array}{l}1.223 \\
(0.23)\end{array}$ \\
\hline $\begin{array}{l}\text { Legal origins } \\
\text { Scandinavian }\end{array}$ & $\begin{array}{l}6.650 * \\
(1.85)\end{array}$ & $\begin{array}{l}1.312 \\
(0.35)\end{array}$ & $\begin{array}{l}1.179 \\
(0.16)\end{array}$ & $\begin{array}{c}0.620 \\
(-0.58)\end{array}$ & $\begin{array}{l}3.630 \\
(1.42)\end{array}$ \\
\hline $\begin{array}{l}\mathrm{N} \text { observations } \\
\mathrm{N} \text { events }\end{array}$ & $\begin{array}{c}104 \\
10\end{array}$ & $\begin{array}{c}169 \\
15\end{array}$ & $\begin{array}{c}253 \\
9\end{array}$ & $\begin{array}{c}113 \\
13\end{array}$ & $\begin{array}{c}184 \\
17\end{array}$ \\
\hline
\end{tabular}

*** Significant at the 1 percent level. ** Significant at the 5 percent level. * Significant at the 10 percent level.

The table reports hazard ratios, t-statistics are in parentheses. 
Table 5. Multivariate hazards model: benchmark rules

The table reports estimation results of a Cox proportional hazards model, using Efron's approximation for ties. Event is the adoption of a benchmark rule regarding the respective component of board structure. In equation (8), the three legal families are replaced by an indicator variable 'civil law' that conflates the civil law categories, because none of the codes from German legal origin countries reached the benchmark definition of 'Separation chairman/CEO'. Likelihood ratio test statistics are calculated for models including the three sets of predictors measuring diffusion, ownership structure, and legal origins compared with nested models. 'LR test (Diffusion)' reports test statistics for a model with 'Diffusion' and 'Diffusion' ${ }^{2}$ as predictors against the null model, 'LR test (Ownership)' for a model including the ownership variables against a model with the diffusion variables, and 'LR test (Legal origins)' for a model including the legal origins variables against a model with the diffusion variables. The LR test for the models with ownership variables is computed by excluding observations from the nested model for which ownership data is missing.

Predictors Event: adoption of benchmark rule

(1)

(2)

(3)

(4)

(5)

(6)

(7)

(9)

(10)

Diffusion non-executive

directors

Diffusion number

independent directors

Diffusion definition of

independence

Diffusion separation

chairman/CEO

Diffusion committee

structure

Diffusion $^{2}$

0.953

$0.921^{* * * *}$

$0.927^{* *}$

$(-1.54)$

$(-0.95)$

$(-2.63)$

$(-2.38)$

Interaction with time

Ownership foreign

0.060

0.119

$(-0.89)$

$3.397 * * * \quad 2.604 * *$

(2.17)

$(-0.86)$

$\begin{array}{ll}3.216^{*} & 2.971 * \\ (1.83) & (1.73)\end{array}$

(1.83)

(1.73)

$3.339 * * \quad 3.030 * *$

(2.30) (2.37)

$0.916^{* *}$

$0.923 * *$

(-1.98)

$1.745^{* * *}$

(2.51) (2.50)

0.990* $\quad 0.988^{*}$

$(-1.75) \quad(-1.90)$

$0.0002 *$

$(-1.77)$

0.880

0.294 


\begin{tabular}{|c|c|c|c|c|c|c|c|c|c|c|}
\hline $\begin{array}{l}\text { Ownership financial } \\
\text { institutions }\end{array}$ & $\begin{array}{c}0.002 \\
(-1.07)\end{array}$ & & $\begin{array}{l}207.5 \\
(1.43)\end{array}$ & & $\begin{array}{l}27.84 \\
(0.65)\end{array}$ & & $\begin{array}{l}11.58 \\
(0.54)\end{array}$ & & $\begin{array}{l}0.269 \\
(-0.37)\end{array}$ & \\
\hline $\begin{array}{l}\text { Concentrated ownership } \\
\text { structure }\end{array}$ & $\begin{array}{l}0.128 * * \\
(-2.24)\end{array}$ & & $\begin{array}{l}0.262 * * \\
(-2.01)\end{array}$ & & $\begin{array}{l}0.104 * * \\
(-2.24)\end{array}$ & & $\begin{array}{l}0.316^{*} \\
(-1.69)\end{array}$ & & $\begin{array}{l}0.369 * \\
(-1.68)\end{array}$ & \\
\hline Legal origins German & & $\begin{array}{l}2.182 \\
(0.74)\end{array}$ & & $\begin{array}{c}0.104 * * \\
(-2.53)\end{array}$ & & $\begin{array}{c}0.966 \\
(-0.03)\end{array}$ & & & & $\begin{array}{l}1.495 \\
(0.36)\end{array}$ \\
\hline Legal origins French & & $\begin{array}{l}1.129 \\
(0.13)\end{array}$ & & $\begin{array}{c}0.061 * * \\
(-2.54)\end{array}$ & & $\begin{array}{c}0.477 \\
(-0.61)\end{array}$ & & & & $\begin{array}{l}1.288 \\
(0.24)\end{array}$ \\
\hline $\begin{array}{l}\text { Legal origins } \\
\text { Scandinavian }\end{array}$ & & $\begin{array}{l}9.240 * \\
(1.91)\end{array}$ & & $\begin{array}{l}1.696 \\
(0.63)\end{array}$ & & $\begin{array}{l}1.483 \\
(0.31)\end{array}$ & & & & $\begin{array}{l}4.242 \\
(1.18)\end{array}$ \\
\hline Legal origins civil law & & & & & & & & $\begin{array}{l}0.209 * \\
(-1.88)\end{array}$ & & \\
\hline $\begin{array}{l}-2 \mathrm{LL} \\
\text { LR test (Diffusion) } \\
\text { LR test (Ownership) }\end{array}$ & $\begin{array}{c}37.66 \\
2.002 \\
6.289 *\end{array}$ & 40.74 & $\begin{array}{c}61.72 \\
8.176^{* *} \\
7.554 *\end{array}$ & 61.92 & $\begin{array}{c}33.9 \\
5.640 * \\
10.39 * *\end{array}$ & 43.28 & $\begin{array}{c}43.52 \\
9.276^{* * *} \\
3.459\end{array}$ & 48.68 & $\begin{array}{c}68.32 \\
10.93 * * * \\
2.872\end{array}$ & 74.3 \\
\hline LR test (Legal origins) & & 4.746 & & $13.66 * * *$ & & 1.053 & & $3.233 *$ & & 2.691 \\
\hline $\begin{array}{l}\mathrm{N} \text { observations } \\
\mathrm{N} \text { events }\end{array}$ & $\begin{array}{c}101 \\
10\end{array}$ & $\begin{array}{c}104 \\
10\end{array}$ & $\begin{array}{c}165 \\
14\end{array}$ & $\begin{array}{c}169 \\
15\end{array}$ & $\begin{array}{c}247 \\
9\end{array}$ & $\begin{array}{c}253 \\
9\end{array}$ & $\begin{array}{c}112 \\
12\end{array}$ & $\begin{array}{c}113 \\
13\end{array}$ & $\begin{array}{c}180 \\
16\end{array}$ & $\begin{array}{c}184 \\
17\end{array}$ \\
\hline
\end{tabular}

*** Significant at the 1 percent level. ** Significant at the 5 percent level. * Significant at the 10 percent level.

The table reports hazard ratios, $\mathrm{t}$-statistics are in parentheses. 